\title{
Water-Clear Cell Adenocarcinoma
}

National Cancer Institute

\section{Source}

National Cancer Institute. Water-Clear Cell Adenocarcinoma. NCI Thesaurus. Code C4156.

An adenocarcinoma characterized by the presence of malignant epithelial cells with clear, often vacuolated or foamy cytoplasm. 